\title{
Familial frontotemporal dementia with neuronal intranuclear inclusions is not a polyglutamine expansion disease
}

\author{
Ian R Mackenzie ${ }^{1}$, Stefanie L Butland ${ }^{2}$, Rebecca S Devon ${ }^{3}$, Emily Dwosh ${ }^{4}$, \\ Howard Feldman ${ }^{4}$, Caroline Lindholm ${ }^{4}$, Scott J Neal ${ }^{5}$, BF Francis Ouellette ${ }^{2}$ \\ and Blair R Leavitt*5
}

\begin{abstract}
Address: ${ }^{1}$ Department of Pathology, University of British Columbia, Vancouver, BC, Canada, ${ }^{2}$ UBC Bioinformatics Centre, Department of Medical Genetics, University of British Columbia, Vancouver, BC, Canada, ${ }^{3}$ Medical Genetics Section, University of Edinburgh, Molecular Medicine Centre, Western General Hospital, Edinburgh, UK, ${ }^{4}$ Division of Neurology, Department of Medicine, University of British Columbia, Vancouver, BC, Canada and ${ }^{5}$ Centre for Molecular Medicine and Therapeutics, Department of Medical Genetics, University of British Columbia, Vancouver, $\mathrm{BC}$, Canada
\end{abstract}

Email: Ian R Mackenzie - ian.mackenzie@vch.ca; Stefanie L Butland - butland@bioinformatics.ubc.ca;

Rebecca S Devon - Rebecca.Devon@ed.ac.uk; Emily Dwosh - edwosh@helix.medgen.ubc.ca; Howard Feldman - hfeldman@interchange.ubc.ca; Caroline Lindholm - lindholm@helix.medgen.ubc.ca; Scott J Neal - sneal@cmmt.ubc.ca; BF Francis Ouellette - francis@bioinformatics.ubc.ca; Blair R Leavitt* - bleavitt@cmmt.ubc.ca

* Corresponding author

Published: 3I August 2006

BMC Neurology 2006, 6:32 doi:10.1 186/147|-2377-6-32
Received: 27 June 2006

Accepted: 3I August 2006

This article is available from: http://www.biomedcentral.com/I47I-2377/6/32

(c) 2006 Mackenzie et al; licensee BioMed Central Ltd.

This is an Open Access article distributed under the terms of the Creative Commons Attribution License (http://creativecommons.org/licenses/by/2.0), which permits unrestricted use, distribution, and reproduction in any medium, provided the original work is properly cited.

\begin{abstract}
Background: Many cases of frontotemporal dementia (FTD) are familial, often with an autosomal dominant pattern of inheritance. Some are due to a mutation in the tau- encoding gene, on chromosome 17, and show an accumulation of abnormal tau in brain tissue (FTDP-17T). Most of the remaining familial cases do not exhibit tau pathology, but display neuropathology similar to patients with dementia and motor neuron disease, characterized by the presence of ubiquitinimmunoreactive (ub-ir), dystrophic neurites and neuronal cytoplasmic inclusions in the neocortex and hippocampus (FTLD-U). Recently, we described a subset of patients with familial FTD with autopsy-proven FTLD-U pathology and with the additional finding of ub-ir neuronal intranuclear inclusions (NII). NII are a characteristic feature of several other neurodegenerative conditions for which the genetic basis is abnormal expansion of a polyglutamine-encoding trinucleotide repeat region. The genetic basis of familial FTLD-U is currently not known, however the presence of NII suggests that a subset of cases may represent a polyglutamine expansion disease.
\end{abstract}

Methods: We studied DNA and post mortem brain tissue from 5 affected members of 4 different families with NII and one affected individual with familial FTLD-U without NII. Patient DNA was screened for CAA/CAG trinucleotide expansion in a set of candidate genes identified using a genome-wide computational approach. Genes containing CAA/CAG trinucleotide repeats encoding at least five glutamines were examined $(n=63)$, including the nine genes currently known to be associated with human disease. CAA/CAG tract sizes were compared with published normal values (where available) and with those of healthy controls $(n=94)$. High-resolution agarose gel electrophoresis was used to measure allele size (number of CAA/CAG repeats). For any alleles estimated to be equal to or larger than the maximum measured in the control population, the CAA/ CAG tract length was confirmed by capillary electrophoresis. In addition, immunohistochemistry 
using a monoclonal antibody that recognizes proteins containing expanded polyglutamines (IC2) was performed on sections of post mortem brain tissue from subjects with NII.

Results: No significant polyglutamine-encoding repeat expansions were identified in the DNA from any of our FTLD-U patients. NII in the FTLD-U cases showed no IC2 immunoreactivity.

Conclusion: We find no evidence to suggest that autosomal dominant FTLD-U with NII is a polyglutamine expansion disease.

\section{Background}

Frontotemporal dementia (FTD, OMIM: 600274) is a neurodegenerative disease characterized by abnormalities in personality, behaviour and language with relative early preservation of episodic memory [1,2]. The pathology underlying clinical FTD is heterogeneous [3]. In some cases, post mortem examination discloses abnormal accumulations of the microtubule associated protein tau in neurons and/or glial cells. However, several recent studies have demonstrated that the most common pathology associated with clinical FTD is the presence of dystrophic neurites and neuronal cytoplasmic inclusions in the cerebral cortex and hippocampus that are immunoreactive for ubiquitin (ub-ir) but negative for tau, synuclein and intermediate filament proteins (FTLD-U) [4,5].

FTD is often familial, usually with an autosomal dominant pattern of inheritance. Various studies have demonstrated genetic linkage to loci on chromosomes 3, 9 and 17 [6-11]. The gene on chromosome 3 and one of the genes on chromosome 9 have recently been identified (chmp2B and valosin-containing protein, respectively) $[12,13]$. Some cases that show linkage to chromosome 17 are found to have mutations in the gene for tau (MAPT) and all such cases show tau pathology [14,15]. Familial FTLD-U has been linked to several different loci on chromosome 9 and to chromosome 17q21 [6,7,10,11,16]. Interestingly, the 17q21 locus contains MAPT, and yet these cases do not have any tau pathology and have not had any tau mutations identified $[6,7,11]$. It remains unclear whether these cases are due to some, as yet, unrecognized abnormality in MAPT or whether there is another gene on $17 \mathrm{q} 21$ that is responsible for familial FTLD-U.

Recently, we reported that a subset of patients with familial FTLD-U have the additional post mortem finding of unusual, lentiform, ub-ir neuronal intranuclear inclusions (NII) $[11,17]$. At least some of the cases of familial FTLDU with NII are ones that have shown linkage to the $17 q 21$ locus $[6,7,11]$. NII are uncommon in neurodegenerative disease in general, but are a characteristic pathological feature of several conditions for which the genetic basis is abnormal expansion of a polyglutamine-encoding CAG trinucleotide repeat within the gene (examples include Huntington's disease (HD) and several types of spinocer- ebellar ataxia (SCA) [18-20]. The NII observed in these diseases are composed in part of aggregates of the expanded-repeat proteins. In this study, we explore the possibility that autosomal dominant FTLD-U with NII is a polyglutamine expansion disease.

\section{Methods Study cohort}

Six patients with familial FTD, from five different families, were included in the study. In all families studied here, the pattern of inheritance suggested an autosomal dominant trait with a high degree of penetrance as previously described $[11,17]$. There was no evidence of genetic anticipation in any of the families. Five of the study patients were deceased and each was from a different family. Postmortem neuropathological examination confirmed the presence of ub-ir neuronal cytoplasmic inclusions characteristic of FTLD-U [Figure $1 \mathrm{a}, \mathrm{b}$ ] and an absence of significant tau and $\alpha$-synuclein pathology (not shown). In four deceased patients (cases 1-4), numerous ub-ir NII were also observed. NII had a characteristic lentiform shape and were most numerous in small neurons of the frontotemporal neocortex and striatum [Figure 1c] [17]. The fifth deceased patient had FTLD-U type pathology but no NII (case 6). One living patient with FTD was also included in the study; he was the cousin of one of the deceased study patients with FTLD-U and NII (case 5). Therefore, the six study patients represented four families with FTLD-U with NII (cases 1-5) and one family with FTLD-U without NII (case 6).

\section{Immunohistochemistry}

Post mortem brain tissue from the four deceased study patients with previously confirmed NII was evaluated. Formalin fixed, paraffin-embedded tissue sections from frontal cortex and striatum (areas with maximal numbers of NII), were immunostained using the Ventana ES automated system (Ventana, Tuscon, AZ) with primary antibodies against ubiquitin (DAKO, anti-ubiquitin; 1:500, following microwave antigen retrieval) and proteins with expanded polyglutamine domains (Chemicon, 1C2; 1:100 following formic acid pre-treatment). Tissue sections from two patients with known polyglutamine expansion diseases (one HD and one SCA1) were included as positive controls. 


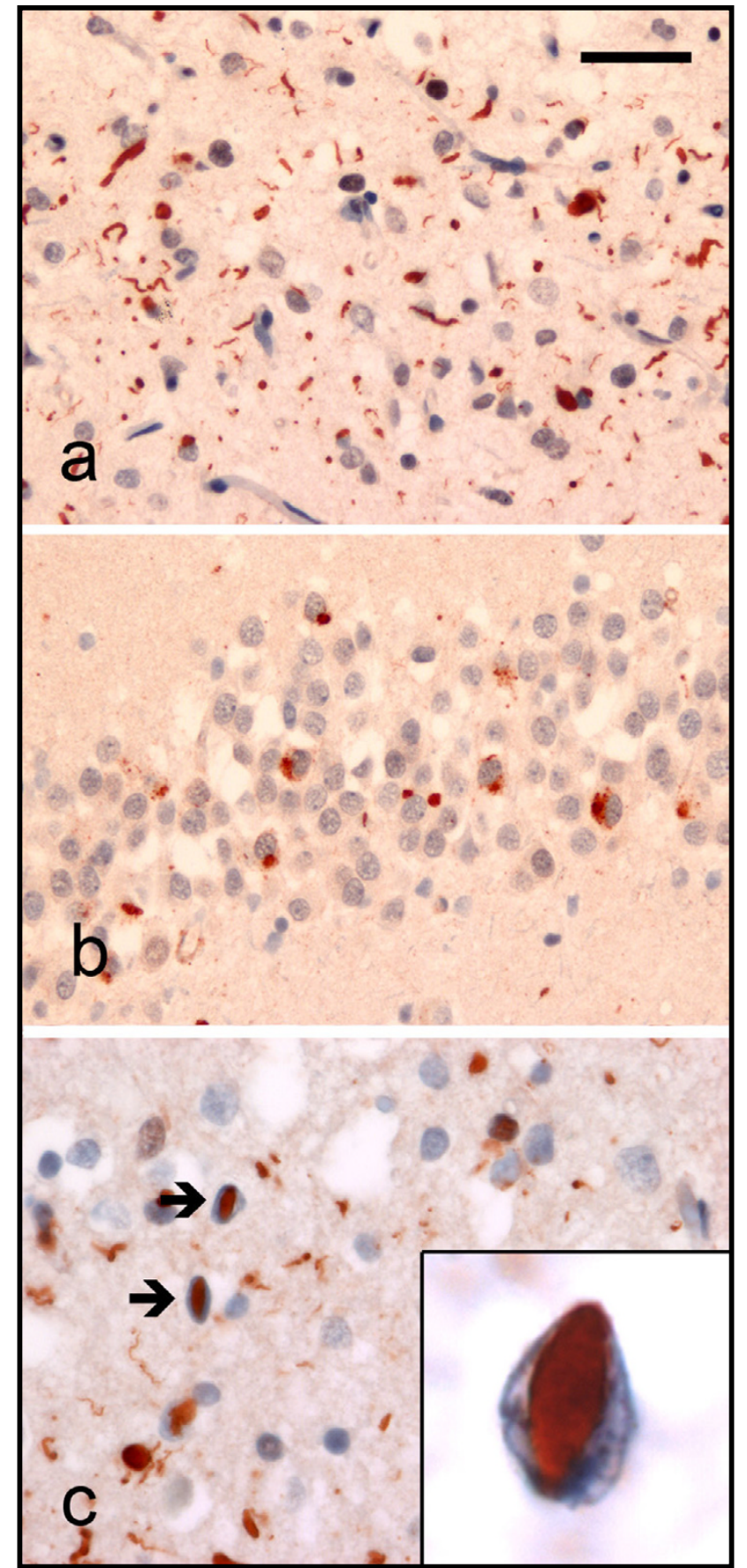

Figure I

Neuropathologic analysis of brain tissue from FTLDUpatients. Ubiquitin immunohistochemistry in cases of familial FTLD-U demonstrates staining of (a) neurites and neuronal cytoplasmic inclusions in the superficial cerebral neocortex, (b) neuronal cytoplasmic inclusions in hippocampal dentate granule cells, and (c) neuronal intranuclear inclusions in the cerebral neocortex (arrows). Scale bar; (a) and (b) $40 \mu \mathrm{m}$, (c) $25 \mu \mathrm{m}$, insert $6 \mu \mathrm{m}$.

\section{Genetic analysis of polyglutamine-encoding genes}

Using a computational approach, we have previously identified 63 genes in the human genome that contain tracts of CAG/CAA trinucleotide repeats which encode at least five consecutive glutamines (Butland et al., in submission). FTLD-U patient DNA was screened for expansions in these trinucleotide repeat tracts $(n=64)$, including the nine tracts whose expansion is currently known to cause neurodegenerative disorders in humans. One gene (PCQAP) contains two distinct polyglutamineencoding tracts that were screened separately, hence the disparity in tract number versus gene number.

Gene-specific PCR primers were used to amplify the repeat-containing loci from the patient DNA, and the amplicons were subjected to high-resolution gel electrophoresis to measure allele size. Metaphor agarose gels (3\% w/v, Mandel Scientific) were run overnight at low voltage in re-circulated buffer. Under such conditions, it is possible to resolve small allelic differences [see Additional file 1]. Gel data were digitised and interpreted with IMAGE $^{\circledast}$ software, and product sizing was estimated to be accurate within 6 base pairs. The length of CAG/CAA tracts was inferred from the overall allele length based on calibration data we obtained by directly sequencing several alleles from each locus. In no case did we observe allele length differences that arose from sequence changes outside of the repeat tract. Thus, all allele size changes correspond to differences in the repeat tract alone. From the present data we cannot, however, determine where in the repeat tract, such as in the longest contiguous CAG tract, the expansion is occurring.

The data presented herein refer to the longest uninterrupted tract of CAG and CAA trinucleotides in the given gene. These values were compared to published data (for known disease loci) and to data obtained from a control group ( $\mathrm{n}=94)$ of unaffected individuals (Butland et al., in submission). Based on the above resolution limit, all alleles estimated to be 6 or more b.p. longer than the longest control allele were subjected to confirmatory capillary electrophoresis on an ABI 3700 DNA Analyzer (Applied Biosystems) and subsequent analysis using GeneMapper software (Applied Biosystems).

This research was carried out in compliance with the Helsinki Declaration, and ethical approval was provided by the Clinical Research Ethics Board of the University of British Columbia (certificate C03-0449).

\section{Results}

Neuropathologic analysis of FTLD-U brain tissue

Ubiquitin-positive neurites and neuronal cytoplasmic inclusions were identified in the superficial cerebral neocortex of the FTLD-U patients (Figure 1a), and similar 
Table I: Genetic analysis of FTLD-U DNA samples reveals no significant CAG/CAA repeat expansions in candidate polyglutamineencoding genes.

\begin{tabular}{|c|c|c|c|c|c|c|c|c|}
\hline & \multirow{2}{*}{$\begin{array}{l}\text { Gene Name (associated polyQ dis- } \\
\text { ease, CAA/CAG tract length of small- } \\
\text { est disease-cuasing allele) }{ }^{a}\end{array}$} & \multirow{2}{*}{$\begin{array}{c}\text { Control Samples }(n=94) \\
\text { estimated CAA/CAG } \\
\text { tract length }\end{array}$} & \multicolumn{6}{|c|}{ FTD Patients estimated CAA/CAG tract length } \\
\hline & & & case $I^{b}$ & case $2^{b}$ & case $3^{b}$ & case $4^{b}$ & case $5^{b}$ & case $6^{c}$ \\
\hline \multirow[t]{9}{*}{$\mathbf{A}$} & AR (SBMA, 38) & $10-37$ & 22 & 19 & 20 & 21,23 & 19 & 24 \\
\hline & ATNI (DRPLA, 48) & $10-39$ & 18,23 & 18,20 & 20,23 & 19 & 15,19 & 15 \\
\hline & ATXNI (SCAI, 39) & $6-39$ & 15,20 & 15,20 & 16 & 15,20 & 15,20 & $|4,2|$ \\
\hline & ATXN2 (SCA2, 37) & $25-41$ & 22 & 22 & 22 & 22 & 22 & 22 \\
\hline & ATXN3 (SCA3/MJD, 5 I) & $14-42$ & 15 & 9 & 9 & 9 & 17 & na \\
\hline & ATXN7 (SCA7, 36) & $4-35$ & 10 & 11 & 10 & 10 & 10 & 10 \\
\hline & CACNAIA $($ SCA6, 20) & $4-18$ & $|2,2|^{d}$ & 13,16 & 15 & 14 & 14 & 13 \\
\hline & HD $(H D, 36)$ & $10-35$ & 14,15 & 12,17 & 17,21 & 15,17 & 12,14 & 12 \\
\hline & TBP $(\mathrm{SCA} \mid 7,49)$ & $38-61$ & 39,44 & 38,41 & 38,43 & 36,39 & 38,47 & 38,42 \\
\hline \multirow[t]{36}{*}{ B } & ARID3B & $11-13$ & 12 & 12 & 12,16 & 12,16 & 13,16 & 13 \\
\hline & ASCLI & $5-24$ & 13,17 & 13 & 13,17 & 13,18 & 13,18 & 12 \\
\hline & BMP2K & $22-31$ & 26 & 26 & 26 & 26 & 26 & 26 \\
\hline & $\mathrm{Cl} 4$ orf4 & $19-24$ & 22,25 & 22,25 & 23 & 23 & 24 & 23 \\
\hline & CXorf6 & $11-12$ & 12 & 12 & 12 & 11 & 11 & 12 \\
\hline & DCPIB & $10-12$ & 12 & na & 12 & 11,12 & 11,12 & 11,12 \\
\hline & KCNN3 & $10-43$ & 18 & 17,18 & na & 19,21 & $|8,2|$ & 18,20 \\
\hline & MEDI 2 & 26 & 27 & 26 & 26 & 26 & 26 & 26 \\
\hline & MEF2A & $9-16$ & 12,15 & II & 12 & 10,11 & 11,14 & 11 \\
\hline & MINKI & $5-6$ & 6 & 6 & 6 & 6 & 6 & 7 \\
\hline & MLL2 & $6-9$ & 9 & 9 & 9 & 9 & 9 & 9 \\
\hline & NCOA3 & $25-34$ & 26,29 & 28 & 26,28 & 29 & 28,29 & 28 \\
\hline & NCOA6 & $23-26$ & 25 & 25 & na & 24 & 25 & 25 \\
\hline & NCOR2 & $13-22$ & 17,19 & 17 & 17 & 16,17 & 13,17 & 17,18 \\
\hline & NFAT5 & $|8-2|$ & 19 & 18 & 18 & 18 & na & na \\
\hline & NM 014856 & $13-17$ & 16 & 17 & 14,16 & 17 & 16 & 14,16 \\
\hline & NUMBL & 26 & 18,20 & 18 & 20 & 18,20 & 18,20 & 20 \\
\hline & PCQAPa & $10-18$ & 11 & 11 & 11 & 10 & 10 & 11 \\
\hline & PCQAPb & $11-22$ & 17 & 16 & 16 & 15 & 16 & 16 \\
\hline & PHLDAI & $15-19$ & 15 & 15 & 16 & 15 & 15 & 15 \\
\hline & POLG & $13-16$ & 13 & 14 & 13 & 16,17 & 13 & 13 \\
\hline & POU3F2 & $20-21$ & 15 & 21,22 & 21 & 21 & 21 & 21 \\
\hline & POU6F2 & $7-11$ & 10 & 10 & 10 & 10 & 10 & 10 \\
\hline & PRDMIO & $7-8$ & 8 & 8 & 8 & 8 & 8 & 8 \\
\hline & PRKCBPI & $7-11$ & 8 & 8 & 7 & 8 & 8 & 8 \\
\hline & RAII & $8-20$ & 14 & 14 & 14 & 14 & 14 & 10,14 \\
\hline & RUNX2 & $26-53$ & 22 & 21 & 22 & 23 & 23 & 21 \\
\hline & SATBI & $|2-2|$ & 15 & 15 & 15 & 15 & 15 & 15 \\
\hline & SMARCA2 & $18-25$ & 22 & 22 & 22 & 22 & 22 & 22 \\
\hline & SOCS7 & $7-22$ & 8,12 & 8 & 8 & 8 & 8 & 8 \\
\hline & TFEB & $9-15$ & 12 & 9 & 9 & 9 & 10 & 10 \\
\hline & TNRC4 & $14-17$ & 15 & 15 & 15 & 15 & 15 & 15 \\
\hline & TNRC6B & $7-10$ & 9,10 & 9 & 9 & 9 & 8 & 8 \\
\hline & TNS & $8-11$ & 10,12 & 10 & 9 & 10 & 9 & 10 \\
\hline & ZNFI6I & $8-22$ & 16,17 & 14,20 & 14 & na & 14 & 14 \\
\hline & ZNF384 & $11-20$ & 15 & 16 & 15 & 15 & 20 & 15 \\
\hline \multirow[t]{8}{*}{ C } & ARIDIB & $16-23$ & 18 & 18 & 19 & 19 & 18 & 18 \\
\hline & BAIAPI & $|6-2|$ & 20,24 & 19,25 & 18,19 & 19 & 20 & 17,19 \\
\hline & BRD4 & $8-9$ & 8 & 8 & 8 & 8 & 8 & 8 \\
\hline & C9orf43 & $8-9$ & 9 & 9,12 & 8 & 8 & 9,12 & 8 \\
\hline & CHERP & 12 & 12 & 12 & 12 & 12 & 12 & 12 \\
\hline & $\mathrm{ClZI}$ & 6 & 6 & 6 & 6 & 6 & 6 & 6 \\
\hline & CREBBP & 18 & 18 & 18 & 18 & 18 & 18 & 18 \\
\hline & EP400 & $28-31$ & 30 & 30,34 & 30 & 30 & 31 & 30,34 \\
\hline
\end{tabular}


Table I: Genetic analysis of FTLD-U DNA samples reveals no significant CAG/CAA repeat expansions in candidate polyglutamineencoding genes. (Continued)

$\begin{array}{cccccccc}\text { FOXP2 } & 34-40 & 41 & \text { na } & 41 & 41 & 42 & 42 \\ \text { KIAAI8I7 } & 26-27 & 27 & 28 & 28 & 28 & 27 & 27 \\ \text { KIAA20I8 } & 11-16 & 13 & 14 & 14 & 14 & 12,17 & 12 \\ \text { MAML2 } & 27-31 & 29 & 32,36 & 28 & 28 & 28,31 & 28 \\ \text { MAML3b } & 18 & 19 & 19 & 19 & 19 & 19 & 19 \\ \text { MNI } & 26-30 & 28 & 28 & 28 & 28 & 28 & 28,29 \\ \text { PAXIPIL } & 7 & 9 & 9 & 9 & 8 & 8 & 8 \\ \text { PHCI } & 13-15 & 15 & 15 & 15 & 15 & 15 & 15 \\ \text { ST6GALNAC5 } & 12-14 & 12 & 12 & 12 & 12 & 12 & 12 \\ \text { THAPII } & 18-30 & 24 & 24 & 24,33 & 24 & 24,26 & 24,28 \\ \text { TNRC6A } & 4-8 & 4,8 & 5,8 & 8 & 8 & 5,8 & 8 \\ & & & & & & \end{array}$

a Genes identified in a computational analysis of polyglutamine repeat-containing genes in the human genome. A) Genes known to cause disease via polyglutamine expansion. B) Patient and control samples were both assessed by high resolution agarose gel electrophoresis. C) Control samples were analyzed by capillary electrophoresis (Butland et al., in submission) and patient samples analyzed by high resolution agarose gel electrophoresis.

b FTDL-U patients with NII.

c FTDL-U patient without NII.

d Alleles 6 or more b.p. longer than the largest contol allele (putative expanded alleles) appear in bold type.

Samples of FTLD-U patient DNA with NII (Cases I-5) and without NII (Case 6) were screened for expansions in the CAG/CAA trinucleotide repeat tracts of our candidate genes including known disease genes (A). The CAG/CAA repeat lengths from the FTLD-U subjects were compared with published normal values and with those of healthy controls $(n=94)$, assessed by high resolution agarose gel electrophoresis $(\mathbf{B})$, and/or capillary electrophoresis (C). For the few alleles estimated to be equal to or slightly larger than the maximum measured in our control samples (bold), the CAG/CAA repeat length was confirmed by capillary electrophoresis on an ABI 3700 sequencer using GeneMapper software. Using this approach, no clinically significant CAG/CAA repeat expansions were identified in the DNA from any of our FTLD-U patients.

neuronal cytoplasmic inclusions were found in hippocampal dentate granule cells (Figure 1b). Ub-ir NII were found in the cerebral neocortex (arrows, Figure 1c). NII in the control cases with known polyglutamine disease (HD and SCA1) were immunoreactive for both ubiquitin and 1C2. In contrast, NII in FTLD-U patients were ub-ir, but were $1 \mathrm{C} 2$ negative (data not shown).

\section{Genetic analysis of FTLD-U DNA samples for CAGICAA repeat expansions in polyglutamine-encoding genes}

FTLD-U patient DNA was screened for expansions in the CAA/CAG trinucleotide repeat tracts of our candidate genes (Table 1), and the repeat sizes from the study subjects were compared with published normal values and with those of healthy controls $(\mathrm{n}=94)$ (Butland et al., in submission). Sixteen small putative expanded alleles were detected, while the vast majority of alleles from our FTD patients fell within the range of normal alleles from our unaffected controls. At least one allele was identified in each patient that fell just outside the range observed in our controls samples, and these alleles arose from eight genes (CACNA1A, ARID3B, BAIAP1, C9orf43, EP400, FOXP2, MAML2, PAXIP1L). The largest putative expansion identified consisted of a 15 b.p. ( 5 CAG/CAA) increase over the largest control allele (case 2, MAML2). The exact CAG repeat size of all the putative expanded alleles was confirmed by capillary electrophoresis sizing and/or direct DNA sequencing, and none of these specific alleles was found to be expanded in all of the affected FTDL-U individuals.

\section{Discussion}

We have adapted an inexpensive, high-resolution agarose gel electrophoresis method for the precise sizing of targeted polyglutamine-encoding repeat tracts in the human genome. Using this method, the normal distribution of CAG repeat lengths for known disease loci compared favourably with previously published data and matched the results obtained by direct sequencing of specific alleles, thus confirming the reliability of our method. No significant CAA/CAG repeat expansions were detected at the nine known disease loci in any of the FTLD-U patients. The initial analysis of the data suggested a putative minor expansion in the CACNA1A gene (case 1) by gel electrophoresis that was subsequently refuted by capillary electrophoresis. This method was subsequently applied to 55 candidate loci that we identified as part of our computational screen for polyglutamine-encoding tracts in the human genome (Butland et al., in submission). We identified 15 alleles from seven genes in our FTLD-U patients that were 6 or more b.p. longer than the longest control allele (Table 1, allele sizes in bold text). None of these small expansions consistently correlated with affected FTLD-U status in multiple individuals. An allele of MAML2 harboured the largest putative expansion (15 b.p., case 2). However, according to the annotation of the reference genome, the trinucleotide repeat tract passes through a proposed intron. Thus, it is unclear if in fact this allele would encode an expanded polyglutamine tract in the protein. 
Several factors make it unlikely that the small putative expansions identified are pathogenic. First, there were no genes for which the allele sizes in FTD patients with NII (cases 1-5) were consistently larger than those from the FTD patient without NII (case 6). Second, pathogenic alleles of known human polyglutamine disorders typically encode more than 35 consecutive glutamines whereas none of our putative expanded alleles encode this many.

Our histopathological findings also support the conclusion than FTLD-U with NII is not a polyglutamine expansion disorder. All known polyglutamine expansions disorder include the presence of ub-ir NII which also label with the monoclonal antibody 1C2 [18-20]. The absence of any $1 \mathrm{C} 2$ reactivity in our FTLD-U patient tissue thus makes it unlikely that their NII contain proteins with expanded polyglutamine tracts.

Finally, although only a small number of such families have been reported to date, there is evidence that NII may be a specific pathological marker for FTLD-U linked to the chromosome $17 \mathrm{q} 21$ locus $[6,7,11]$. Our computational approach did not identify any gene in the defined region of interest that contains at least five CAG or CAA repeats, although ubiquitinated intranuclear inclusions are known to occur in triplet repeat disorders encoding for amino acids other than glutamine (alanine), and in disorders caused by expansions in untranslated regions. This region does contain 294 non-CAG trinucleotide repeat tracts of minimum length $5 ; 11$ of which are found within the coding sequences of 6 known and 3 hypothetical genes [21]. Thus, a non-glutamine encoding trinucleotide repeat expansion could still be the basis of the observed phenotype.

\section{Conclusion}

In summary, we find no evidence to suggest that autosomal dominant FTLD-U with NII is a polyglutamine expansion disease. We did not observe immunoreactivity for expanded polyglutamines within FTLD-U brain, nor did we identify any alleles with large polyglutamineencoding repeat expansions in our set of candidate genes, which comprises all of the predicted genes of interest with at least five polyglutamine-encoding CAA/CAG repeats in the human genome. Furthermore, none of the slightly longer alleles from FTLD-U subjects within the candidate genes identified by our computational approach are found within the various linkage regions established in prior studies. Therefore, both our genetic analysis and immunohistochemical data, suggest that the formation of NII in FTLD-U is due to a mechanism other than accumulation of a protein with a polyglutamine expansion.

\section{Competing interests}

The author(s) have no competing interests to disclose.

\section{Authors' contributions}

SLB, RSD, BRL, BFFO, IRM conceived and designed the experiments. HF, CL, ED contributed the genetic and clinical materials. SLB, RSD, IRM performed the experiments. SLB, SJN, IRM analysed the data. SLB, SJN, IRM and BRL wrote the paper and all other authors provided comments.

\section{Note added in proof}

The conclusions of this manuscript have recently been verified by two manuscripts: Baker $\mathrm{M}$ et al, Mutations in progranulin cause tau-negative frontotemporal dementia linked to chromosome 17. Nature. 2006 Aug 24;442(7105):916-9, and Cruts $M$, et al. Null mutations in progranulin cause ubiquitin-positive frontotemporal dementia linked to chromosome 17q21. Nature. 2006 Aug 24;442(7105):920-4. This work identified non-polyglutamine encoding mutations in the gene encoding progranulin as the cause of FTLD-U in the subjects we studied.

\section{Additional material}

\section{Additional File 1}

A comparison of the agarose gel method of CAG repeat allele size measurement with conventional capillary electrophoresis. We have proven the reliability of the agarose gel method by comparing product sizes generated using this technology with results from an ABI PRISM ${ }^{\circledast} 3100$ Genetic Analyzer, and also by direct DNA sequencing of the PCR products. As positive controls for larger fragments, we have also performed this comparison on a set of DNA samples known to harbour an expansion in the HD gene (Supplemental Figure 1). Electrophoresis of a PCR product with a mono-allelic expansion in the HD repeat, by agarose gel electrophoresis (panel A) and by ABI Genetic Analyzer (panel B). The location of the two alleles is marked by green dots (panel $A$ ) or blue peaks (panel $B)$; the dark band with no green dot is the well of the agarose gel. The difference in CAG repeat length between the 'normal' and the 'expanded' allele is identical between both methods.

Click here for file

[http://www.biomedcentral.com/content/supplementary/14712377-6-32-S1.ppt]

\section{Acknowledgements}

The authors wish to thank Soo Sen Lee, Anna Wilkinson, Ashvinder Bhogal, Macaire Man St. Yuen for technical assistance, sample management, and database management, lan Bosdet and Jacquie Schein for early technology development. Funding for this study was provided by the Canadian Institutes of Health Research (operating grant \#74580), the Canadian Genetic Diseases Network, the National Organization for Rare Disorders, and the University of British Columbia. BRL is a ClHR Clinician-Scientist.

\section{References}

I. Neary D, Snowden JS, Gustafson L, Passant U, Stuss D, Black S, Freedman M, Kertesz A, Robert PH, Albert M, Boone K, Miller BL, Cummings J, Benson DF: Frontotemporal lobar degeneration: a consensus on clinical diagnostic criteria. Neurology 1998, 5I:1546-I554. 
2. McKhann GM, Albert MS, Grossman M, Miller B, Dickson D, Trojanowski JQ: Clinical and pathological diagnosis of frontotemporal dementia: report of the Work Group on Frontotemporal Dementia and Pick's Disease. Arch Neurol 200I, 58:1803-1809.

3. Trojanowski JQ, Dickson D: Update on the neuropathological diagnosis of frontotemporal dementias. J Neuropathol Exp Neurol 2001, 60:1 I23-1126.

4. Josephs KA, Holton JL, Rossor MN, Godbolt AK, Ozawa T, Strand K, Khan N, Al-Sarraj S, Revesz T: Frontotemporal lobar degeneration and ubiquitin immunohistochemistry. Neuropathol Appl Neurobiol 2004, 30:369-373.

5. Lipton AM, White CL, Bigio EH: Frontotemporal lobar degeneration with motor neuron disease-type inclusions predominates in $\mathbf{7 6}$ cases of frontotemporal degeneration. Acta Neuropathol (Berl) 2004, 108:379-385.

6. Rosso SM, Kamphorst W, de Graaf B, Willemsen R, Ravid R, Niermeijer MF, Spillantini MG, Heutink P, van Swieten JC: Familial frontotemporal dementia with ubiquitin-positive inclusions is linked to chromosome 17q2 I-22. Brain 200I, I 24:1948-I957.

7. Rademakers R, Cruts M, Dermaut B, Sleegers K, Rosso SM, Van den Broeck M, Backhovens H, van Swieten J, van Duijn CM, Van Broeckhoven $C$ : Tau negative frontal lobe dementia at I7q2I: significant finemapping of the candidate region to a $4.8 \mathrm{cM}$ interval. Mol Psychiatry 2002, 7:1064-1074.

8. Ashworth A, Lloyd S, Brown J, Gydesen S, Sorensen SA, Brun A, Englund E, Humphreys C, Housman D, Badura M, Stanton VJ, Taylor K, Cameron J, Munroe D, Johansson J, Rossor M, Fisher EM, Collinge J: Molecular genetic characterisation of frontotemporal dementia on chromosome 3. Dement Geriatr Cogn Disord 1999, IO Suppl I:93-101.

9. Kovach MJ, Waggoner B, Leal SM, Gelber D, Khardori R, Levenstien MA, Shanks CA, Gregg G, Al-Lozi MT, Miller T, Rakowicz W, Lopate G, Florence J, Glosser G, Simmons Z, Morris JC, Whyte MP, Pestronk A, Kimonis VE: Clinical delineation and localization to chromosome 9p/3.3-p/2 of a unique dominant disorder in four families: hereditary inclusion body myopathy, Paget disease of bone, and frontotemporal dementia. Mol Genet Metab 200I, 74:458-475.

10. Hosler BA, Siddique T, Sapp PC, Sailor W, Huang MC, Hossain A, Daube JR, Nance M, Fan C, Kaplan J, Hung WY, McKenna-Yasek D, Haines JL, Pericak-Vance MA, Horvitz HR, Brown RHJ: Linkage of familial amyotrophic lateral sclerosis with frontotemporal dementia to chromosome 9q21-q22. Jama 2000, 284:1664-1669.

II. Mackenzie IR, Baker M, West G, Woulfe J, Qadi N, Gass J, Cannon A, Adamson J, Feldman H, Lindholm C, Melquist S, Pettman R, Sadovnick AD, Dwosh E, Whiteheart SW, Hutton M, Pickering-Brown SM: A family with tau-negative frontotemporal dementia and neuronal intranuclear inclusions linked to chromosome 17. Brain 2006, I 29:853-867.

12. Skibinski G, Parkinson NJ, Brown JM, Chakrabarti L, Lloyd SL, Hummerich H, Nielsen JE, Hodges JR, Spillantini MG, Thusgaard T, Brandner S, Brun A, Rossor MN, Gade A, Johannsen P, Sorensen SA, Gydesen S, Fisher EM, Collinge J: Mutations in the endosomal ESCRTIII-complex subunit CHMP2B in frontotemporal dementia. Nat Genet 2005, 37:806-808.

13. Watts GD, Wymer J, Kovach MJ, Mehta SG, Mumm S, Darvish D, Pestronk A, Whyte MP, Kimonis VE: Inclusion body myopathy associated with Paget disease of bone and frontotemporal dementia is caused by mutant valosin-containing protein. Nat Genet 2004, 36:377-38I.

14. Hutton M, Lendon CL, Rizzu P, Baker M, Froelich S, Houlden H, Pickering-Brown S, Chakraverty S, Isaacs A, Grover A, et al.: Association of missense and 5 '-splice-site mutations in tau with the inherited dementia FTDP-17. Nature 1998, 393:702-705.

15. Reed LA, Wszolek ZK, Hutton M: Phenotypic correlations in FTDP-I 7. Neurobiol Aging 200I, 22:89-107.

16. Hutton M, Lendon CL, Rizzu P, Baker M, Froelich S, Houlden H, Pickering-Brown S, Chakraverty S, Isaacs A, Grover A, Hackett J, Adamson J, Lincoln S, Dickson D, Davies P, Petersen RC, Stevens M, de Graaff E, Wauters E, van Baren J, Hillebrand M, Joosse M, Kwon JM, Nowotny P, Che LK, Norton J, Morris JC, Reed LA, Trojanowski J, Basun H, Lannfelt L, Neystat M, Fahn S, Dark F, Tannenberg T, Dodd PR, Hayward N, Kwok JB, Schofield PR, Andreadis A, Snowden J, Craufurd D, Neary D, Owen F, Oostra BA, Hardy J, Goate A, van
Swieten J, Mann D, Lynch T, Heutink P: Association of missense and 5 -splice-site mutations in tau with the inherited dementia FTDP-17. Nature 1998, 393:702-705.

17. Vance C, Al-Chalabi A, Ruddy D, Smith BN, Hu X, Sreedharan J, Siddique T, Schelhaas HJ, Kusters B, Troost D, Baas F, de Jong V, Shaw $\mathrm{CE}$ : Familial amyotrophic lateral sclerosis with frontotemporal dementia is linked to a locus on chromosome 9p/3.221.3. Brain 2006, I 29:868-876.

18. Mackenzie IR, Feldman H: Neuronal intranuclear inclusions distinguish familial FTD-MND type from sporadic cases. Acto Neuropathol (Berl) 2003, 105:543-548.

19. Davies SW, Beardsall K, Turmaine M, DiFiglia M, Aronin N, Bates GP: Are neuronal intranuclear inclusions the common neuropathology of triplet-repeat disorders with polyglutaminerepeat expansions? Lancet |998, 35 I:|3|-|33.

20. Trottier Y, Lutz Y, Stevanin G, Imbert G, Devys D, Cancel G, Saudou F, Weber C, David G, Tora L, et al.: Polyglutamine expansion as a pathological epitope in Huntington's disease and four dominant cerebellar ataxias. Nature 1995, 378:403-406.

21. Yamada M, Tsuji S, Takahashi H: Pathology of CAG repeat diseases. Neuropathology 2000, 20:319-325.

\section{Pre-publication history}

The pre-publication history for this paper can be accessed here:

http://www.biomedcentral.com/1471-2377/6/32/prepub
Publish with Bio Med Central and every scientist can read your work free of charge

"BioMed Central will be the most significant development for disseminating the results of biomedical research in our lifetime."

Sir Paul Nurse, Cancer Research UK

Your research papers will be:

- available free of charge to the entire biomedical community

- peer reviewed and published immediately upon acceptance

- cited in PubMed and archived on PubMed Central

- yours - you keep the copyright

Submit your manuscript here:

http://www.biomedcentral.com/info/publishing_adv.asp
BioMedcentral 